\title{
O CONTO DE GENJI, DE VIRGINIA WOOLF
}

\section{THE TALE OF GENJI, BY VIRGINIA WOOLF}

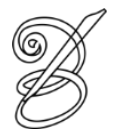

Traduzido por:

Emanuela Carla SIQUEIRA ${ }^{i^{*}}$

Universidade Federal do Paraná

Curitiba, Paraná, Brasil

Resumo: Em 1925, na revista Vogue, a escritora inglesa Virginia Woolf escreveu uma resenha empolgada pela tradução do orientalista Arthur Waley para "O Conto de Genji”, atribuído à escritora e poeta Murasaki Shikibu, considerado um dos primeiros romances japoneses, escrito no começo do século XI. Mesmo que curto, o texto dá conta da prática de crítica literária promovida pela autora na época, aliando a pesquisa na autoria de mulheres e o sentimento do que chamava de leitor/a comum diante de um texto literário, sem amarras acadêmicas.

Palavras-chave: Virginia Woolf. O conto de Genji. Murasaki Shikibu. Literatura japonesa. Autoria de mulheres.

Abstract: In 1925, English writer Virginia Woolf published in Vogue magazine an enthusiastic review of orientalist Arthur Waley's translation of "The Tale of Genji"; written in the early 11th century and attributed to writer and poet Murasaki Shikibu, it is considered to be one of the first Japanese novels. Although brief, the article sustains the practice of literary criticism championed by Woolf at the time by combining the writer's own research of women's authorship and the notion of a "common reader", also by Woolf, in face of a literary text, free from academic restraints.

Keywords: Virginia Woolf. Tale of Genji. Murasaki Shikibu. Japanese Literature. Women's Authorship.

RECEBIDO EM: 5 de setembro de 2019

ACEITO EM: 30 de janeiro 2020

PUBLICADO EM: março 2020 
irginia Woolf (1882-1941) foi um dos principais nomes da literatura inglesa do século XX, teve romances reconhecidos como Mrs. Dalloway (1925) e Orlando (1928), atuou como articuladora e intelectual no grupo londrino de Bloomsbury e foi uma das principais praticantes da técnica de fluxo de consciência. Além de cartas e prática diarística, também foi uma atuante crítica literária, publicando textos em várias revistas da Inglaterra e dos Estados Unidos. Mesmo sendo acusada de impressionista, os ensaios de Virginia Woolf são também peças de exercício da técnica de fluxo de consciência e articulando o deslumbre diante da leitura - observando detalhes de personagens e cenas - ela caminha pelo texto dialogando com a autoria, fortalecendo-a mesmo quando enxerga problemas nas construções.

A tradução do "Conto de Genji", resenha publicada em 1925, na revista Vogue, do romance da escritora japonesa Murasaki Shikibu é importante por vários motivos, desde a ampliação da recepção de Virginia Woolf como crítica literária atuante na época, até novos diálogos para a crítica literária feminista que, costumeiramente, usa como um dos textos base o "Um Teto todo Seu", de Woolf, publicado em 1929. Nesse segundo ponto, "Conto de Genji"

212 se torna uma das primeiras leituras da escritora inglesa, de literaturas de autoria de mulheres além das de língua inglesa e francesa e isso amplia seu olhar para o que ainda era inalcançável nessa autoria. Percebendo as diferenças de escrita com a autoria de homens como Cervantes e Tolstói, por exemplo, ela ainda tece uma crítica pós-colonial diante do que se considera canônico no mundo europeu. 


\section{The Tale of Genji}

Our readers will scarcely need to be reminded that it was about the year 991 that Aelfric composed his Homilies, that his treatises upon the Old and New Testament were slightly later in date, and that both works precede that profound, if obscure, convulsion which set Swegen of Denmark upon the throne of England. Perpetually fighting, now men, now swime, now thickets and swamps, it was with fists swollen with toil, minds contracted by danger, eyes stung with smoke and feet that were cold among the rushes that our ancestors applied themselves to the pen, transcribed, translated and chronicled, or burst rudely, and hoarsely into crude spasms of song.

\section{Sumer is icumen in,}

Lhude sing сисси

- such is their sudden harsh cry. Meanwhile, at the same moment, on the other side of the globe the Lady Murasaki was looking out to her garden, and noticing how ' among the leaves were white flowers with petals half unfolded like the lips of people smiling at their own thoughts'.

While the Aelfrics and the Aelfreds croaked and coughed in England, this court lady, about whom we know nothing, for Mr Waley artfully withholds all information until the six volumes of her novel are before us, was sitting down in her silk dress and trousers with pictures before her and the sound of poetry in her ears, with flowers in her garden and nightingales in the trees, with all day to talk in and all night to dance in - she was sitting down about the year 1000 to tell the story of the life and adventures of Prince Genji. But we must hasten to correct the impression that the Lady Murasaki was in any sense a chronicler. Since her book was read aloud, we may imagine an audience; but her listeners must have been astute, subtle minded, sophisticated men and women. They were grown-up people, who needed no feats

\section{O Conto de Genji}

Nossos leitores e leitoras dificilmente precisam ser lembrados que foi por volta do ano de 991 que Elfrico compôs sua Homilias, um pouco depois os tratados sobre o Antigo e Novo Testamento, e que ambos os trabalhos precedem o intenso, embora obscuro, abalo que coloca Swegen da Dinamarca sobre o trono da Inglaterra. Lutando perpetuamente, ora homens, ora porcos, ora moitas e pântanos, com punhos inchados da labuta, mentes encolhidas pelo perigo, olhos ardendo de fumaça e pés gelados entre os juncos que nossos ancestrais adaptavam à pena, transcrito, traduzido e narrado, ou irrompido de forma rude e rouca nos espasmos primitivos da canção.

\section{Sumer is icumen in,}

Lhude sing cuccu

- tal é seu grito repentino e severo. Enquanto isso, no mesmo momento, no outro lado do globo Lady Murasaki estava olhando para o seu jardim e percebendo como "entre as folhas havia flores brancas com pétalas meio desdobradas como lábios sorrindo aos próprios pensamentos".

Enquanto Aelfrics e Aelfreds tossiam e resmungavam na Inglaterra, essa cortesã, de quem nada sabemos, pois Sr. Waley deteve habilmente toda informação até que os seis volumes de seu romance estivessem diante de nós, estava sentada com seu vestido de seda e calças, diante de pinturas e o som da poesia nos ouvidos, com flores no jardim e rouxinóis nas árvores, o dia todo para conversar e a noite para bailar - ela estava sentada, por volta do ano 1000, para contar a história da vida e das aventuras do príncipe Genji. Mas devemos nos apressar em corrigir a impressão de que Lady Murasaki era, de alguma forma, uma cronista. Uma vez que seu livro fosse lido em voz alta, imaginamos espectadores; mas seus e suas ouvintes devem ter sido astutos, sutis, homens e mulheres sofisticados. Eram pessoas adultas, 
of strength to rivet their attention; no catastrophe to surprise them. They were absorbed, on the contrary, in the contemplation of man's nature; how passionately he desires things that are denied; how his longing for a life of tender intimacy is always thwarted; how the grotesque and the fantastic excite him beyond the simple and straight-forward; how beautiful the falling snow is, and how as he watches it, he longs more than ever for someone to share his solitary joy.

The Lady Murasaki lived, indeed, in one of those seasons which are most propitious for the artist, and, in particular, for an artist of her own sex. The accent of life did not fall upon war; the interests of men did not centre upon politics. Relieved from the violent pressure of these two forces, life expressed itself chiefly in the intricacies of

behaviour, in what men said and what women

214 did not quite say, in poems that break the surface of silence with silver fins, in dance and painting, and in that love of the wildness of nature which only comes when people feel themselves perfectly secure. In such an age as this Lady Murasaki, with her hatred of bombast, her humour, her common sense, her passion for the contrasts and curiosities of human nature, for old houses mouldering away among the weeds and the winds, and wild landscapes, and the sound of water falling,

and mallets beating, and wild geese screaming, and the red noses of princesses, for beauty indeed, and that incongruity which makes beauty still more beautiful, could bring all her powers into play spontaneously. It was one of those moments (how they were reached in Japan and how destroyed we must wait for Mr Waley to explain) when it was natural for a writer to write of ordinary things beautifully, and to say openly to her public. 'It is the common that is wonderful, and if you let yourselves be put off by extravagance and

rant and what is surprising and momentarily impressive you will be cheated of the most sem necessidade de façanha-resistência da sua atenção; nenhuma catástrofe as surpreende. Pelo contrário, eram absorvidas na contemplação da natureza do homem; quão apaixonadamente ele deseja o que lhe foi negado; quanto sua ânsia por uma vida de terna intimidade é sempre frustrada; como o grotesco e o fantástico o excita para além do singelo e óbvio; quão belo é o cair da neve e, quanto mais observa, mais do que nunca anseia por alguém para compartilhar seu deleite solitário.

Lady Murasaki viveu, de fato, em uma daquelas épocas que são mais propícias para artistas e, em particular, para uma artista de seu próprio sexo. A tônica da vida não se espalhou sobre a guerra; os interesses dos homens não se centralizavam na política. Aliviada da violenta pressão dessas duas forças, a vida se expressava principalmente nas complexidades do comportamento, no que diziam os homens e o que não diziam as mulheres, em poemas que quebram a superfície do silêncio com barbatanas de prata, na dança e pintura, e naquele amor pela natureza selvagem que só vem quando as pessoas se sentem perfeitamente seguras. Em um tempo como este, Lady Murasaki, com sua aversão pelo pomposo, seu humor, seu senso comum, sua paixão pelos contrastes e curiosidades da natureza humana, por antigas casas em ruínas entre ervas e ventos e paisagens selvagens e o som da água caindo e marretas batendo e gansos selvagens gritando e princesas de narizes vermelhos, pela beleza de fato, e essa incongruência, que torna a beleza ainda mais bonita, poderia trazer todo os seus poderes, de forma espontânea, ao jogo. Foi em uma dessas ocasiões (como elas eram alcançadas e destruídas no Japão, devemos esperar o Sr. Waley explicar) quando era natural para uma escritora escrever lindamente sobre coisas comuns e manifestar abertamente ao seu público. "É o comum que é maravilhoso, e se vocês se deixarem abater pela extravagância e bravata, pelo que é surpreendente e momentaneamente grandioso, serão privados 
profound of pleasure. ' For there are two kinds of artists, said Murasaki: one who makes trifles to fit the fancy of the passing day, the other who 'strives to give real beauty to the things which men actually use, and to give to them the shapes which tradition has ordained.' How easy it is, she said, to impress and surprise; 'to paint a raging sea monster riding a storm' - any toy

maker can do that, and be praised to the skies. 'But ordinary hills and rivers, just as they are, houses such as you may see anywhere, with all their real beauty and harmony of form - quietly to draw such scenes as this, or to show what lies behind some intimate hedge that is folded away far from the world, and thick trees upon some unheroic hill, and all this with befitting care for composition, proportion, and the like such works demand the highest master's utmost skill and must needs draw the common craftsman into a thousand blunders.

Something of her charm for us is doubtless accidental. It lies in the fact that when she speaks of 'houses such as you may see anywhere' we at once conjure up something graceful, fantastic, decorated with cranes and chrysanthemums, a thousand miles removed from Surbiton and the Albert Memorial. We give her, and luxuriate in giving her, all those advantages of background and atmosphere which we are forced to do without in England today. But we should wrong her deeply if, thus seduced, we prettified and sentimentalised an art which, exquisite as it is, is without a touch of decadence, which, for all its sensibility, is fresh and childlike and without a trace of the exaggeration or languor of an outworn civilisation. But the essence of her charm lies deeper far than cranes and chrysanthemums. It lies in the belief which she held so simply and was, we feel, supported in holding by Emperors and waiting maids, by the air she breathed and the flowers she saw - that the true artist 'strives to give real beauty to the do mais profundo prazer". Existem dois tipos de artistas diz Murasaki: aquele que cria trivialidades para se adequar aos caprichos do dia que passa, o outro que "se esforça para dar verdadeira beleza às coisas que os homens realmente usam, e dar-lhes as formas que a tradição demanda". Como é fácil, ela diz, impressionar e surpreender; "pintar um furioso monstro marinho galgando uma tempestade" - qualquer entalhador pode fazêlo e ser elogiado até os céus. "Mas colinas e rios comuns, exatamente como são, casas como as que você pode ver em qualquer lugar, com toda a sua beleza e harmonia na forma - de forma tranquila, desenhar cenas como essa, ou mostrar o que há por trás de uma cerca viva que está encurvada longe do mundo, e árvores grossas em cima de uma colina nada heróica, e tudo isso com apropriado cuidado de composição, proporção e afins - essas obras exigem o máximo de habilidade do maior mestre, e necessidades levam o artesão comum a mil equívocos."

Algo do charme dela para nós é sem dúvida acidental. Reside no fato de que quando ela fala de "casas como as que você pode ver em qualquer lugar", invocamos algo gracioso, fantástico, decorado com grous e crisântemos, a mil quilômetros de Surbiton e do Albert Memorial. Concedemos a ela, e nos deleitamos em conceder-lhe, todos os incentivos do contexto e atmosfera que estão em falta na Inglaterra atual. Mas deveríamos tirá-la profundamente a razão se, assim seduzidos, embelezamos sentimentalizamos uma arte que, por mais requintada que seja, não tem um toque de decadência, que, apesar de toda a sua sensibilidade, é nova e infantil e sem um traço do exagero ou languidez de uma civilização ultrapassada. Mas a essência do encanto dela é mais profunda do que os grous e crisântemos. Encontra-se na crença que ela manteve de forma tão simples - e estava, sentimos, apoiada por Imperadores $\mathrm{e}$ camareiras, pelo ar que ela respirava e as flores que viu - de modo que o verdadeiro 
things which men actually use and to give to them the shapes which tradition has ordained'. On she went, therefore, without hesitation or self-consciousness, effort or agony, to tell the story of the enchanting boy - the Prince who danced 'The Waves of the Blue Sea', so beautifully that all the princes and great gentlemen wept aloud; who loved those whom he could not possess; whose libertinage was tempered by the most perfect courtesy; who played enchantingly with children, and preferred, as his women friends knew, that the song should stop before he had heard the end. To light up the many facets of his mind, Lady Murasaki, being herself a woman, naturally chose the medium of other women's minds. Aoi, Asagao, Fujitsubo, Murasaki Yugao Suyetsumuhana, the beautiful, the red-nosed, the cold, the passionate - one after another they turn their clear or freakish light upon the gay young man at the centre, who flies, who pursues,

216 who laughs, who sorrows, but is always filled with the rush and bubble and chuckle of life.

Unhasting, unresting, with unabated fertility, story after story flows from the brush of Murasaki. Without this gift of invention we might well fear that the tale of Genji would run dry before the six volumes are filled. With it, we need have no such foreboding. We can take our station and watch, through $\mathrm{Mr}$ Waley's beautiful telescope, the new star rise in perfect confidence that it is going to be large and luminous and serene - but not, nevertheless, a star of the first magnitude. No; the lady Murasaki is not going to prove herself the peer of Tolstoy and Cervantes or those other great story-tellers of the Western world whose ancestors were fighting or squatting in their huts while she gazed from her lattice window at flowers which unfold themselves 'like the lips of people smiling at their own thoughts'. Some element of horror, of terror, or sordidity, some root of experience has been removed from the Eastern world so that crudeness is impossible artista "se esforça para dar verdadeira beleza às coisas que os homens realmente usam, e dar-lhes as formas que a tradição demanda". Assim ela continuou, portanto, sem hesitação ou autoconsciência, esforço ou agonia, a contar a história do menino encantador - o Príncipe que dançava As Ondas do Mar Azul, tão lindamente que todos os príncipes e grandes cavalheiros choravam em voz alta; que amava aqueles a quem ele não podia possuir; cuja libertinagem era temperada pela mais perfeita cortesia; que brincava encantado com as crianças e preferia, como sabiam suas amigas mulheres, que a música parasse antes de ele ouvir o fim. Para iluminar as muitas facetas de sua mente, Lady Murasaki, sendo ela mesma uma mulher, naturalmente escolheu como meio as mentes de outras mulheres. Aoi, Asagao, Fujitsubo, Murasaki Yugao Suyetsumuhana, a bela, a do nariz vermelho, a fria, a apaixonada - uma a uma, acendem sua luz clara ou extravagante sobre o jovem alegre no centro, que voa, que busca, que ri, que sofre, mas sempre é preenchido com o ímpeto e borbulha e gracejo da vida.

Desafiante, inquietante, com uma fertilidade inabalável, história atrás de história aflui do pincel de Murasaki. Sem este dom da invenção nós podemos muito bem temer que o conto de Genji seque antes que os seis volumes sejam preenchidos. Com isso, não precisamos de tamanho agouro. Podemos tomar nossa posição e observar, através do belo telescópio do Sr. Waley, a nova estrela nascer em perfeita confiança de que será grande, luminosa e serena - mas não, no entanto, uma estrela de primeira magnitude. Não; a senhora Murasaki não vai se provar como par de Tolstói e Cervantes ou aqueles outros grandes contadores de histórias do Ocidente, cujos ancestrais estavam lutando ou fazendo ocupações em cabanas, enquanto ela olhava de sua janela de treliça para flores que desdobravam-se "como lábios sorrindo aos próprios pensamentos". Algum elemento de horror, terror ou sordidez, algumas raízes da experiência foram removidas do Oriente 
and coarseness out of the question, but with it too has gone some vigour, some richness, some maturity of the human spirit, failing which the gold is silvered and the wine mixed with water. All comparisons between Murasaki and the great Western writers serve but to bring out her perfection and their force. But it is a beautiful world; the quiet lady with all her breeding, her insight and her fun, is a perfect artist; and for years to come we shall be haunting her groves, watching her moons rise and her snow fall, hearing her wild geese cry and her flutes and lutes and flageolets tinkling and chiming, while the Prince tastes and tries all the queer savours of life and dances so exquisitely that men weep, but never passes the bounds of decorum, or relaxes his search for something different, something finer, something withheld. para que a crudeza seja impossível e a rudeza fora de questão, mas com isso também se foi algum vigor, alguma riqueza, alguma maturidade do espírito humano, sem isso o ouro será prateado e o vinho misturado com água. Todas as comparações entre Murasaki e os grandes escritores do Ocidente servem apenas para revelar sua perfeição e sua força. Mas é um belo mundo; a silenciosa dama com toda a sua criação, percepção e humor, é uma artista perfeita; e por anos assombraremos seus bosques, observando suas luas surgirem e sua neve cair, ouvindo seus gansos selvagens chorarem e suas flautas e alaúdes e flajolés tilintantes e harmonizados, enquanto o Príncipe prova e experimenta todos os estranhos sabores da vida e dança tão requintadamente que os homens choram, mas nunca passa os limites do decoro, ou relaxa sua busca por algo diferente, algo mais refinado, algo retido.

\section{Sobre a tradutora}

Emanuela Siqueira é doutoranda em Estudos Literários pela UFPR, tradutora e pesquisadora de Virgínia Woolf como ensaísta. Traduziu o volume de ensaios A Leitora Incomum (Arte e Letra, 2017). Pesquisa crítica literária feminista e estudos feministas na tradução.

\section{REFERÊNCIA}

WOOLF, Virginia; MCNEILLE, Andrew. The essays of Virginia Woolf. Vol.4, 1925-1928. New York: Harcourt, 1989, p.265-268.

\footnotetext{
i* Emanuela Carla SIQUEIRA - Graduada em Letras - Inglês (2010) pela Universidade Comunitária da Região de Chapecó. Mestre (2019) e doutoranda em Letras pela Universidade Federal do Paraná. Universidade Federal do Paraná, Setor de Ciências Humanas, Programa de Pós-Graduação em Letras. Curitiba, Paraná, Brasil.

Currículo acadêmico: http://lattes.cnpq.br/3390880589439115

ORCID: https://orcid.org/0000-0001-6810-412X

E-mail: emanuelacsiqueira@gmail.com
} 